\title{
Two are not always better than one: ligand optimisation for long-living light-emitting electrochemical cells $\dagger$
}

\author{
Rubén D. Costa, ${ }^{a}$ Enrique Ortí, ${ }^{a}$ Henk J. Bolink, ${ }^{* a}$ Stefan Graber, ${ }^{b}$ Catherine E. Housecroft, ${ }^{b}$ \\ Markus Neuburger, ${ }^{b}$ Silvia Schaffner ${ }^{b}$ and Edwin C. Constable ${ }^{* b}$
}

Received (in Cambridge, UK) 2nd December 2008, Accepted 10th February 2009

First published as an Advance Article on the web 26th February 2009

DOI: $10.1039 / \mathbf{b 8 2 1 6 0 2 a}$

\begin{abstract}
The complex $\left[\operatorname{Ir}(\mathrm{ppy})_{2}(\mathrm{dpbpy})\right]\left[\mathrm{PF}_{6}\right](\mathrm{Hppy}=2$-phenylpyridine, dpbpy $=6,6^{\prime}$-diphenyl-2,2' $2^{\prime}$-bipyridine) has been prepared and evaluated as an electroluminescent component for light-emitting electrochemical cells (LECs); the complex exhibits two intramolecular face-to-face $\pi$-stacking interactions and long-lived LECs have been constructed; the device characteristics are not significantly improved in comparison to analogous LECs with 6-phenyl-2,2'-bipyridine.
\end{abstract}

Light-emitting electrochemical cells (LECs) are a minimalist derivative of organic light-emitting devices (OLEDs) and in their simplest form consist of a film of an ionic transition metal complex placed between two electrodes. ${ }^{1,2}$ LECs offer considerable technological advantages over OLEDs as they require a less reactive cathode material ( $\mathrm{Al}$ instead of $\mathrm{Ca}$ or $\mathrm{Mg}$ ) because the device is no longer dependent upon the work function of the electrode and hence do not require stringent protection from environmental oxygen or water. The disadvantage of LECs is the short operating lifetime, in the order of hours to days, compared to OLEDs. ${ }^{3-5} \mathrm{We}$ have recently reported the use of intra- and intermolecular face-to-face $\pi$-stacking for the stabilisation of the ground and excited state of electroluminescent iridium complexes and shown that this leads to exceptionally long-living LEC devices. ${ }^{6,7}$ The long lifetimes of these devices establish LECs as a viable alternative to OLED technology. In $[\operatorname{Ir}(\mathrm{ppy})(\mathrm{pbpy})]^{+}$ (Hppy = 2-phenylpyridine, pbpy $=6$-phenyl-2,2'-bipyridine $)$ the pendant phenyl group of the pbpy ligand forms a face-to-face $\pi$-stack with the metallated ring of a ppy ligand (3.2-3.5 $\AA$ ). This interaction minimises the expansion of the metal-ligand bonds in the excited state and precludes the attack by water and other nucleophiles resulting in the long observed lifetimes. We concluded that analogous complexes with $6,6^{\prime}$-diphenyl-2,2'-bipyridine would have an even greater stabilisation of the excited state as the two pendant phenyl groups would stack with different ppy ligands giving a very "tight" complex.

\footnotetext{
${ }^{a}$ Instituto de Ciencia Molecular, Universidad de Valencia, PO Box 22085, Valencia, Spain.E-mail: henk.bolink@uv.es;

Fax: + 3496354 3273; Tel: + 34963544416

${ }^{b}$ Department of Chemistry, University of Basel, CH 4056 Basel, Switzerland.E-mail: Edwin.constable@unibas.ch; Fax: + 4161267 1005; Tel: + 41612671001

$\dagger$ Electronic supplementary information (ESI) available: Synthesis and characterisation of $\left[\operatorname{Ir}(\mathrm{ppy})_{2}(\mathrm{dpbpy})\right]\left[\mathrm{PF}_{6}\right]$, device preparation and characteristics. CCDC 711832. For ESI and crystallographic data in CIF or other electronic format see DOI: $10.1039 / \mathrm{b} 821602 \mathrm{a}$
}

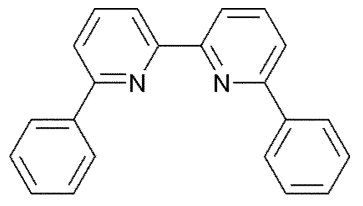

dpbpy

The ligand 6,6'-diphenyl-2,2'-bipyridine, dpbpy, was obtained from the reaction of four equivalents of phenyllithium with $2,2^{\prime}$-bipyridine in THF followed by oxidation of the intermediate tetrahydro-species with $\mathrm{MnO}_{2}$ according to the general procedure of Sauvage et al. ${ }^{8}$ The reaction of dpbpy with the chloro-bridged dimer $\left[(\text { ppy })_{2} \operatorname{Ir}(\mu-\mathrm{Cl})_{2} \operatorname{Ir}(\text { ppy })_{2}\right]^{9}$ under standard conditions (reflux in $1: 1 \mathrm{CH}_{2} \mathrm{Cl}_{2}-\mathrm{MeOH}$ in the presence of $\left.\mathrm{Ag}\left[\mathrm{PF}_{6}\right]\right)^{10}$ resulted in a smooth conversion to $\left[\operatorname{Ir}(\mathrm{ppy})_{2}(\mathrm{dpbpy})\right]^{+}$ from which the orange salt $\left[\operatorname{Ir}(\mathrm{ppy})_{2}(\mathrm{dpbpy})\right]\left[\mathrm{PF}_{6}\right]$ was obtained in $89 \%$ yield. The complex was fully characterised by conventional methods $\dagger$ and exhibited two peaks with similar intensity in the ESMS spectrum at $m / z$ 809.2 $\left[\mathrm{M}-\mathrm{PF}_{6}\right]^{+}$and $501.1\left[\mathrm{M}-\mathrm{dpbpy}-\mathrm{PF}_{6}\right]^{+}$, respectively. The orange colour is associated with a weak and broad MLCT absorption at $474 \mathrm{~nm}$ $\left(\mathrm{CH}_{3} \mathrm{CN}, \varepsilon=920 \mathrm{M}^{-1} \mathrm{~cm}^{-1}\right)$ and the complex is luminescent exhibiting an emission in $\mathrm{MeCN}$ solution with a maximum at $595 \mathrm{~nm}$ with a lifetime $\tau=0.6 \mu$ s and a quantum yield (PLQE) of 3\%.

We have determined the structure of $\left[\operatorname{Ir}(\mathrm{ppy})_{2}(\mathrm{dpbpy})\right]\left[\mathrm{PF}_{6}\right] \ddagger$ and the $\left[\operatorname{Ir}(\mathrm{ppy})_{2}(\mathrm{dpbpy})\right]^{+}$cation present in the lattice is shown in Fig. 1a. The $\mathrm{Ir}-\mathrm{N}(\mathrm{ppy})$ $(2.0504(17), 2.0341(17) \AA$ ) and $\mathrm{Ir}-\mathrm{C}(\mathrm{ppy})$ distances $(2.0120(18), 2.012(2) \AA)$ closely resemble those previously reported for $\left[\operatorname{Ir}(\mathrm{ppy})_{2}(\mathrm{pbpy})\right]\left[\mathrm{PF}_{6}\right]^{6}(\mathrm{Ir}-\mathrm{N}, 2.036(3)-2.068(3)$, Ir-C, 2.004(3)-2.025(3) $\AA$ ). The $\mathrm{Ir}-\mathrm{N}(\mathrm{bpy})$ distances (2.2017(18)-2.2254(19) §) are, however, significantly longer than those in $\left[\operatorname{Ir}(\text { ppy })_{2}(\right.$ pbpy)][PF $](2.148(3)-2.215(3) \AA)$, which is a consequence of the $\pi$-stacking of the pendant phenyl groups. The pendant phenyl rings exhibit the expected $\pi$-stacking with the ppy ligands; the phenyl ring containing C39 lies 3.1-3.3 $\AA$ from the ppy containing N1 and that containing C33 3.0-3.35 $\AA$ from the ppy containing N2. The dihedral angle between the two pyridine rings of the bpy is $20.7^{\circ}$, which compares favourably with angles of $18.4^{\circ}$ and $20.7^{\circ}$ for the two independent cations in the unit cell of $\left[\operatorname{Ir}(\mathrm{ppy})_{2}(\mathrm{pbpy})\right]\left[\mathrm{PF}_{6}\right]$. We stress here that the intramolecular $\pi$-stacking is a direct and inevitable consequence of the ligand structure and will be present in the solid state, solution and thin film phases. To summarise, as observed from the crystal structure, the use of the dpbpy ligand for optimising the 

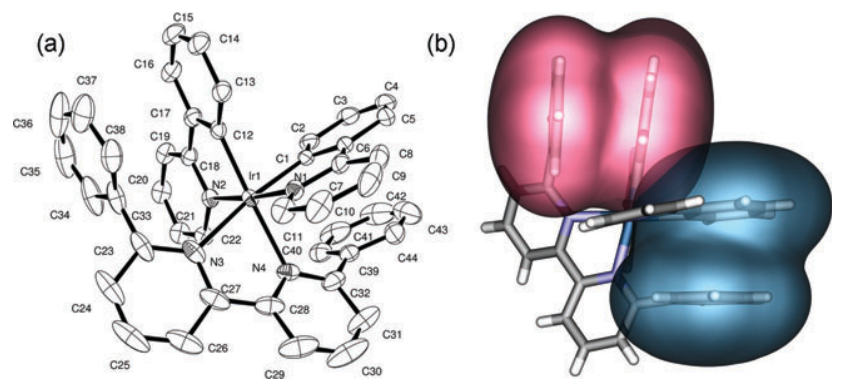

Fig. 1 (a) ORTEP representation of the structure of the $\left[\operatorname{Ir}(\mathrm{ppy})_{2}(\mathrm{dpbpy})\right]^{+}$cation present in $\left[\operatorname{Ir}(\mathrm{ppy})_{2}(\mathrm{dpbpy})\right]\left[\mathrm{PF}_{6}\right]$ showing the numbering scheme adopted; thermal ellipsoids are depicted at $50 \%$ probability. Hydrogen atoms have been omitted for clarity. Selected bond lengths ( $(\AA)$ and angles $\left({ }^{\circ}\right)$ : Ir1-N1 2.0504(17), Ir1-N2 2.0341(17), Ir1-N3 2.2017(18), Ir1-N4 2.2254(19), Ir1-C1 2.0120(18), Ir1-C12 2.012(2); N1-Ir1-N2 174.32(7), N1-Ir1-N3 96.44(7), N2-Ir1-N3 87.56(7), N1-Ir1-N4 83.10(7), N2-Ir1-N4 101.82(7), N3-Ir1-N4 76.18(8), N1-Ir1-C1 80.32(8), N2-Ir1-C1 96.15(8), N3-Ir1-C1 172.84(8), N4-Ir1-C1 97.03(7), N1-Ir1-C12 94.71(7), N2-Ir1-C12 80.31(7), N3-Ir1-C12 105.34(8), N4-Ir1-C12 177.49(7), C1-Ir1-C12 81.37(7). (b) Representation of the $\left[\operatorname{Ir}(\text { ppy })_{2}(\mathrm{dpbpy})\right]^{+}$cation emphasising the face-to-face $\pi$-stacking of the pendant phenyl groups with the ppy ligands.

$\pi$-stacking is successful. However, this double $\pi$-stacking results in an unexpected distortion of the complex, in particular an expansion of the $\mathrm{M}-\mathrm{N}$ coordination sphere is observed which is likely to make the excited state of the complex more open to reaction with adventitious nucleophiles.

Multiple LECs were prepared, and device characteristics optimised, from $\left[\operatorname{Ir}(\mathrm{ppy})_{2}(\mathrm{dpbpy})\right]\left[\mathrm{PF}_{6}\right]$ using the methodology previously reported; ${ }^{2,3}$ an ITO covered substrate was coated with a $0.1 \mu \mathrm{m}$ spin-coated layer of polyethylenedioxythiophenepolystyrene sulfonic acid (PEDOT:PSS) followed by a $80 \mathrm{~nm}$ spin-coated layer of $4: 1$ [ $\operatorname{Ir}(\mathrm{ppy})_{2}(\mathrm{dpbpy})\left[\mathrm{PF}_{6}\right]-1$-butyl-3methylimidazolium hexafluorophosphate and finally an aluminium layer as cathode. The ionic liquid (IL) 1-butyl-3methylimidazolium (BMIP) is incorporated to shorten the turn-on time of the device. ${ }^{2,3,11}$ Characteristics of devices at other ratios of IL to complex are presented in the ESI. $\dagger$

The temporal behaviour of electroluminescent devices containing $\left[\operatorname{Ir}(\mathrm{ppy})_{2}(\mathrm{pbpy})\right]\left[\mathrm{PF}_{6}\right]$ and $\left[\operatorname{Ir}(\mathrm{ppy})_{2}(\mathrm{dpbpy})\right]\left[\mathrm{PF}_{6}\right]$ is depicted in Fig. 2. Immediately obvious from these two graphs is the similarity of the behaviour of the devices using the pbpy and dpbpy complexes. In both cases, the build up of the light output is extremely slow resulting in turn-on times $\left(t_{\mathrm{on}}\right)$ of several days. It is possible to reduce this extremely long $t_{\mathrm{on}}$, either by adding more IL or by pre-biasing the devices with short intervals of higher voltages. ${ }^{11,12}$ For a better comparison between the two devices we did not employ these methods for the data herein reported. After reaching the maximum luminance, both devices show a slow decrease in luminance versus time and reach a value of $50 \%$ of the maximum luminance after approximately $1300 \mathrm{~h}$. This time is referred to as the lifetime $\left(t_{1 / 2}\right)$. Thus, the turn-on time and the lifetime are similar for devices employing the pbpy and dpbpy complexes. In addition, the current efficacy $\left(2.7\right.$ and $\left.3.1 \mathrm{~cd} \mathrm{~A}^{-1}\right)$, the external quantum efficiency (EQE: $1 \%$ and $1.1 \%$ ) and the power efficiency $\left(2.8\right.$ and $\left.3.3 \mathrm{Lm} \mathrm{W}^{-1}\right)$ displayed by
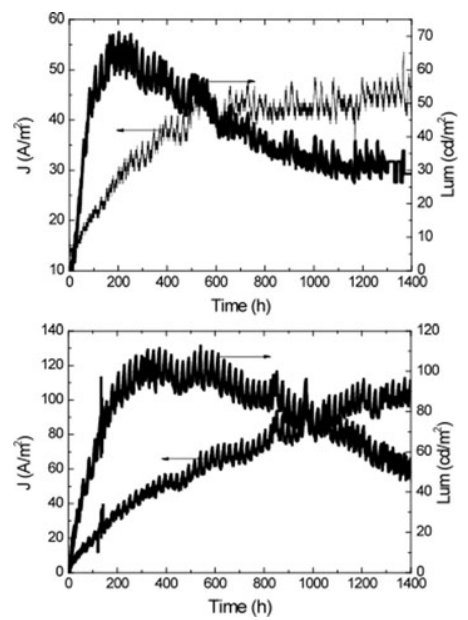

Fig. 2 Current density and luminance data for two LECs ITO/PEDOT:PSS/[Ir-complex][PF $]-I L(4 \quad:$ 1)/Al, in which the $\left[\operatorname{Ir}(\mathrm{ppy})_{2}(\mathrm{dpbpy})\right]\left[\mathrm{PF}_{6}\right]$ (top) and $\left[\operatorname{Ir}(\mathrm{ppy})_{2}(\mathrm{pbpy})\right]\left[\mathrm{PF}_{6}\right]$ (bottom) complexes are employed at an applied bias of $3 \mathrm{~V}$.

the $\left[\operatorname{Ir}(\text { ppy })_{2}(\mathrm{dpbpy})\right]^{+}$and the $\left[\operatorname{Ir}(\mathrm{ppy})_{2}(\mathrm{pbpy})\right]^{+}$devices are also similar. We can categorically state that these device lifetime data are the best ever reported except those published with devices containing $\left[\operatorname{Ir}(\mathrm{ppy})_{2}(\mathrm{pbpy})\right]\left[\mathrm{PF}_{6}\right]$ operated with a pre-biasing method. ${ }^{6}$

The main difference between the two devices lies in the absolute values of the observed luminances. The devices incorporating $\left[\operatorname{Ir}(\mathrm{ppy})_{2}(\mathrm{pbpy})\right]\left[\mathrm{PF}_{6}\right]$ have significantly higher luminance values than those using $\left[\operatorname{Ir}(\mathrm{ppy})_{2}(\mathrm{dpbpy})\right]\left[\mathrm{PF}_{6}\right]$, 110 versus $70 \mathrm{~cd} \mathrm{~m}^{-2}$, respectively. The lifetime of organic luminescent devices depends, in general, strongly on the luminance values at which they are operated. To take this into account in LEC devices, Kalyuzhny et al. proposed the use of the total photon flux $\left(E t_{1 / 5}\right)$ emitted up to the time the luminance reaches $1 / 5$ th of the maximum value $\left(t_{1 / 5}\right)$ for a cell area of $3 \mathrm{~mm}^{2} .^{3}$ By extrapolating the lifetime curves, $E t_{1 / 5}$ values of 13.6 and $6.9 \mathrm{~J}$ are obtained for the devices using $\quad\left[\operatorname{Ir}(\text { ppy })_{2}(\right.$ pbpy $\left.)\right]\left[\mathrm{PF}_{6}\right]$ and $\quad\left[\operatorname{Ir}(\mathrm{ppy})_{2}(\mathrm{dpbpy})\right]\left[\mathrm{PF}_{6}\right]$, respectively, which are significantly larger than the best value reported in the literature $(0.27 \mathrm{~J}) .^{2}$ Hence, taking the different luminance levels and the total photon flux data into account, one must conclude that the device using $\left[\operatorname{Ir}(\mathrm{ppy})_{2}(\mathrm{dpbpy})\right]\left[\mathrm{PF}_{6}\right]$ is less stable than the device using $\left[\operatorname{Ir}(\mathrm{ppy})_{2}(\mathrm{pbpy})\right]\left[\mathrm{PF}_{6}\right]$, thereby showing that two phenyl groups on the bpy are not better than one phenyl group.

In an attempt to understand why one phenyl group is better than two, density functional theory (DFT) calculations were performed at the B3LYP/(6-31G**/LANL2DZ) level on $\left[\operatorname{Ir}(\mathrm{ppy})_{2}(\mathrm{pbpy})\right]^{+}$and $\left[\operatorname{Ir}(\mathrm{ppy})_{2}(\mathrm{dpbpy})\right]^{+}$cations. The geometries of the singlet ground state $\left(\mathrm{S}_{0}\right)$, the emitting triplet state $\left(\mathrm{T}_{1}\right)$ and the metal-centered triplet state $\left({ }^{3} \mathrm{MC}\right)$ were fully optimized for both complexes. Calculations accurately reproduce the face-to-face $\pi-\pi$ stacking observed in the solid state for $\left[\operatorname{Ir}(\mathrm{ppy})_{2}(\mathrm{dpbpy})\right]^{+}$between the pendant phenyl rings of the bpy ligand with the adjacent ppy ligands. The intramolecular $\pi-\pi$ interaction is preserved for the lowest triplet excited state $T_{1}$. This makes the complex more robust in the excited emitting state and reduces the possibility 


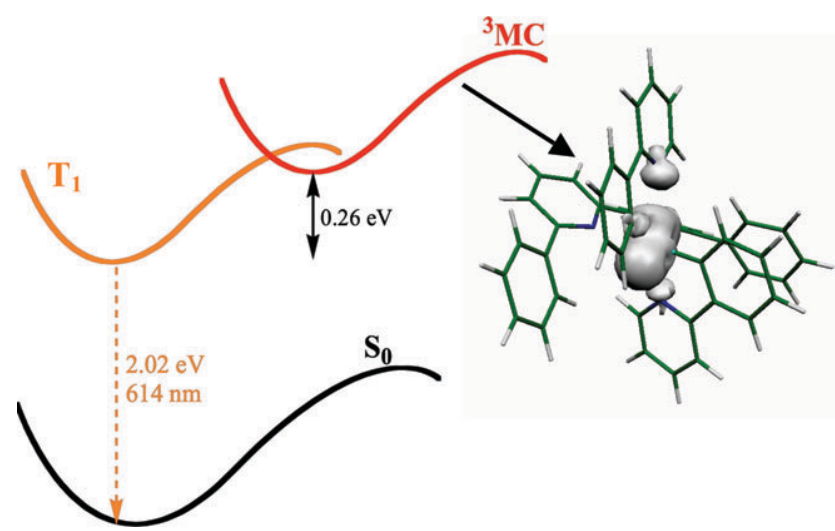

Fig. 3 Schematic energy diagram showing the relative energy of the $\mathrm{T}_{1}$ and ${ }^{3} \mathrm{MC}$ excited states and the vertical emission calculated from $\mathrm{T}_{1}$ for $\left[\operatorname{Ir}(\mathrm{ppy})_{2}(\mathrm{dpbpy})\right]^{+}$. The spin density $\left(0.005 \mathrm{e} \mathrm{bohr}^{-3}\right.$ contours $)$ calculated for the ${ }^{3} \mathrm{MC}$ state of $\left[\operatorname{Ir}(\mathrm{ppy})_{2}(\mathrm{dpbpy})\right]^{+}$is also shown.

for ligand-exchange reactions leading to the degradation of the complex.

State $\mathrm{T}_{1}$ originates from the HOMO $\rightarrow$ LUMO excitation and is calculated to lie 2.22 and $2.32 \mathrm{eV}$ above the $\mathrm{S}_{0}$ state (adiabatic energy difference) for $\left[\operatorname{Ir}(\mathrm{ppy})_{2}(\mathrm{pbpy})\right]^{+}$and $\left[\operatorname{Ir}(\mathrm{ppy})_{2}(\mathrm{dpbpy})\right]^{+}$, respectively. For both complexes, the emitting $T_{1}$ state is described as a mixture of metal-to-ligand and ligand-to-ligand charge transfer $\left({ }^{3} \mathrm{MLCT}\right.$ and ${ }^{3} \mathrm{LLCT}$, respectively) due to the participation of both the Ir atom and the phenyl rings of the ppys in the HOMO while the LUMO is fully located on the bpy ligand (see Fig. S5 in the ESI $\dagger)$. The structure of the $\left[\operatorname{Ir}(\mathrm{ppy})_{2}(\mathrm{dpbpy})\right]^{+}$complex in its ${ }^{3} \mathrm{MC}$ state is similar to that obtained for the $\left[\operatorname{Ir}(\mathrm{ppy})_{2}(\mathrm{pbpy})\right]^{+}$ complex (Table $\mathrm{S} 1 \dagger)$. However, the relative energy position of the ${ }^{3} \mathrm{MC}$ state with respect to the emitting triplet state is significantly different. In the case of the $\left[\operatorname{Ir}(p p y)_{2}(p b p y)\right]^{+}$ complex, the ${ }^{3} \mathrm{MC}$ state is calculated after geometry relaxation to lie at approximately $0.60 \mathrm{eV}$ above the emitting $\mathrm{T}_{1}$ state. In constrast, the ${ }^{3} \mathrm{MC}$ state in the $\left[\operatorname{Ir}(\mathrm{ppy})_{2}(\mathrm{dpbpy})\right]^{+}$complex is located at only $0.26 \mathrm{eV}$ above the $\mathrm{T}_{1}$ state (Fig. 3 ). Hence, the probability of populating the ${ }^{3} \mathrm{MC}$ states increases from $\left[\operatorname{Ir}(\text { ppy })_{2}(\mathrm{pbpy})\right]^{+}$to $\left[\operatorname{Ir}(\mathrm{ppy})_{2}(\mathrm{dpbpy})\right]^{+}$, thereby increasing the probability for non-radiative decay to the ground state and degradation reactions.

In conclusion, a new cationic iridium(III) complex has been prepared that exhibits a double intramolecular $\pi$-stacking between the two phenyl groups of the dpbpy ligand and different cyclometallated ppy ligands, resulting in an intramolecular cage formation. When used as the active component in a light-emitting electrochemical cell, the device exhibits extraordinarily long lifetimes of around $1300 \mathrm{~h}$. Although very long, somewhat surprisingly the lifetime is not increased with respect to a device using a similar complex that can only form one phenyl-ppy intramolecular $\pi$-stack. One reason for this is attributed to the distortion of the planarity of the bpy ligand domain when the two attached phenyl groups $\pi$-stack with the phenyl groups of the ppy ligands. Quantum chemical calculations show that the energy difference between the emitting triplet and the metal-centred triplet state has decreased which renders the complex more susceptible to emission losses and degradation reactions. Thus, in this case two is not better than one.

We would like to thank the European Union (Heteromolmat, STRP 516982), ESF Eurocores-05SONS-FP-021, the Spanish Ministry of Science and Innovation (MICINN) (Grants MAT2006-28185-E, MAT2007-61584, CSD2007-00010, and CTQ2006-14987-C02-02), the Generalitat Valenciana, European FEDER funds, the Swiss National Science Foundation, the University of Basel, the Swiss Nanoscience Institute and the Swiss National Center of Competence in Research "Nanoscale Science". H.J.B. and R.D.C. acknowledge the support of the Program "Ramon y Cajal" and a FPU grant, respectively, of the MICINN.

\section{Notes and references}

$\ddagger \mathrm{C}_{44} \mathrm{H}_{32} \mathrm{~F}_{6} \mathrm{IrN}_{4} \mathrm{P}, M=953.95$, orange block, monoclinic, space group $P 2_{1} / c, a=13.6575(6), b=8.8865(4), c=29.8329(12) \AA$, $\beta=95.286(2)^{\circ}, U=3605.3(3) \AA^{3}, Z=4, D_{\mathrm{c}}=1.757 \mathrm{Mg} \mathrm{m}^{-3}$, $\mu\left(\mathrm{Mo}-\mathrm{K}_{\alpha}\right)=3.819 \mathrm{~mm}^{-1}, T=123 \mathrm{~K}, 20603$ reflections collected. Refinement of 12996 reflections (559 parameters) with $I>3 \sigma(I)$ converged at final $R 1=0.0263(R 1$ all data $=0.0543)$, $\mathrm{w} R 2=0.0254(\mathrm{w} R 2$ all data $=0.0293), R_{\mathrm{int}}=0.044$, gof $=1.082$ CCDC 711832.

1 J. Slinker, D. Bernards, P. L. Houston, H. D. Abruña, S. Bernhard and G. G. Malliaras, Chem. Commun., 2003, 2392.

2 J. D. Slinker, J. Rivnay, J. S. Moskowitz, J. B. Parker, S. Bernhard, H. D. Abruña and G. G. Malliaras, J. Mater. Chem., 2007, 17, 2976

3 G. Kalyuzhny, M. Buda, J. McNeill, P. Barbara and A. J. Bard, J. Am. Chem. Soc., 2003, 125, 6272.

4 H. J. Bolink, L. Cappelli, E. Coronado, M. Graetzel, E. Ortí, R. D. Costa, M. Viruela and M. K. Nazeeruddin, J. Am. Chem. Soc., 2006, 128, 14786.

5 L. J. Soltzberg, J. Slinker, S. Flores-Torres, D. Bernards, G. G. Malliaras, H. D. Abruna, J. S. Kim, R. H. Friend, M. D. Kaplan and V. Goldberg, J. Am. Chem. Soc., 2006, 128, 7761.

6 H. J. Bolink, E. Coronado, R. D. Costa, E. Ortí, M. Sessolo, S. Graber, K. Doyle, M. Neuburger, C. E. Housecroft and E. C. Constable, Adv. Mater., 2008, 20, 3910.

7 S. Graber, K. Doyle, M. Neuburger, C. E. Housecroft, E. C. Constable, R. D. Costa, E. Ortí, D. Repetto and H. J. Bolink, J. Am. Chem. Soc., 2008, 130, 14944.

8 C. O. Dietrich-Buchecker, P. A. Marnot and J.-P. Sauvage, Tetrahedron Lett., 1982, 23, 5291.

9 M. Nonoyama, Bull. Chem. Soc. Jpn., 1974, 47, 767.

10 M. Lepeltier, T. K.-M. Lee, K. K.-W. Lo, L. Toupet, H. Le Bozec and V. Guerchais, Eur. J. Inorg. Chem., 2005, 110.

11 S. T. Parker, J. D. Slinker, M. S. Lowry, M. P. Cox, S. Bernhard and G. G. Malliaras, Chem. Mater., 2005, 17, 3187.

12 E. S. Handy, A. J. Pal and M. F. Rubner, J. Am. Chem. Soc., 1999, 121, 3525 . 